Egyptian Journal of Aquatic Biology \& Fisheries

Zoology Department, Faculty of Science,

Ain Shams University, Cairo, Egypt.

ISSN $1110-6131$

Vol. 24(5): 523 - 538 (2020)

www.ejabf.journals.ekb.eg

\title{
Fishing gears, catch composition and length at first capture of the common fish species in Bardawil lagoon, Egypt
}

\author{
Sahar F. Mehanna ${ }^{1 *}$, Abdel Hamid M.S. Eid ${ }^{2}$, Badiaa A. Ali ${ }^{2}$, Mohammed S. Aabed ${ }^{2}$
}

${ }^{1}$ Fish Population dynamics Lab, National Institute of Oceanography and Fisheries, Egypt

${ }^{2}$ Faculty of Agriculture, Department of Animal and Fish Resources, Suez Canal University

*Corresponding Author: sahar_mehanna@yahoo.com

ARTICLE INFO

Article History:

Received: July 30, 2020

Accepted: Aug. 19, 2020

Online: Aug. 22, 2020

Keywords:

Bardawil lagoon,

fishing gears, catch composition, catch trend, management

\section{ABSTRACT}

Bardawil Lagoon is one of the northern lakes in Egypt and it is a part of the Mediterranean coastal lands of Sinai. It plays an essential role in fish production in Egypt, where it produces very economically important fish species such as seabass, seabream, sole, grey mullet, and white grouper. Bardawil lagoon is the least polluted wetland in Egypt and represents one of the least polluted in the entire Mediterranean region with an average area of about $650 \mathrm{Km}^{2}$ and employing up to 3,000 fishermen. The fishery in Bardawil lagoon is seasonal generally from early April to the end of December. This measure was taken to protect the seabream and seabass leaving the lagoon for the spawning migration. In Bardawil lagoon, total annual commercial landings varied between 2226 and 5410 tons during the last 20 years (Annual statistical report 2018). In 2018, only 2610 tons were landed corresponded to a value of almost 130 million LE. A number of fishing methods are used in the lagoon including Dabba or trammel nets, ElBouss or veranda, Kalsa or trawl nets and Lines or sinner. The present work investigated the fishing methods used in Bardawil lagoon, its characteristics, the catch composition, catch trend, and the length at first capture of the most common fish species in the lagoon.

\section{INTRODUCTION}

Egyptian Fisheries (which includes the management, catching, processing, marketing of fish stocks) and aquaculture (the farming of fish) provide an important source of food, employment, income and recreation for Egyptian people and Millions of Egyptian depend upon fish and fisheries for their livelihoods (Mehanna, 2020).

Bardawil lagoon (Fig. 1) is one of the northern lakes in Egypt and it is a part of the Mediterranean coastal lands of Sinai. It is an important source of local and economic fishes in North Sinai, and it plays an essential role in the fish production in Egypt, where it produces very economically important species of fishes such as seabass, seabream, sole, grey mullet, eel, meager and white grouper. Bardawil lagoon is a shallow hypersaline lagoon, that extends to about $85 \mathrm{~km}$ length with a maximum width of $22 \mathrm{~km}$, and 
range in depth from 0.3 to $3 \mathrm{~m}$. It is occupying much of the Mediterranean coast of Sinai and separated from the sea by a sandbar that varies in width between $100 \mathrm{~m}$ and $1 \mathrm{~km}$. Bardawil lagoon is the least polluted wetland in Egypt and represents one of the least polluted in the entire Mediterranean region with an average area of about $650 \mathrm{Km}^{2}$ and employing some of 3,000 fishermen. The fishery in Bardawil lagoon is seasonal generally from early April to the end of December; all fishing activities are prohibited in winter, from January to the end of March. These measures were taken to protect the seabream and seabass leaving the lagoon for spawning migration. A number of fishing methods are used in the lagoon including Dabba or trammel nets, El-Bouss or veranda, Kalsa or trawl nets, Lines or sinnar, El-Dahbana nets and El-Tair nets (Mehanna, 2006a\&b; Mehanna, 2013; Mehanna et al., 2013; Farouk, 2014; Salman 2014; Mehanna et al., 2019).

One of the main challenges that facing the lagoon development is the fishing gears used. Although Egypt took some regulations for the conservation of the lagoon fisheries, unfortunately these regulations couldn't ensure the sustainability of the lagoon and the conservation of commercial fish stocks. So, the present study will focus on the fishing gears characteristics used in the Bardawil lagoon and their impacts on the lagoon production.

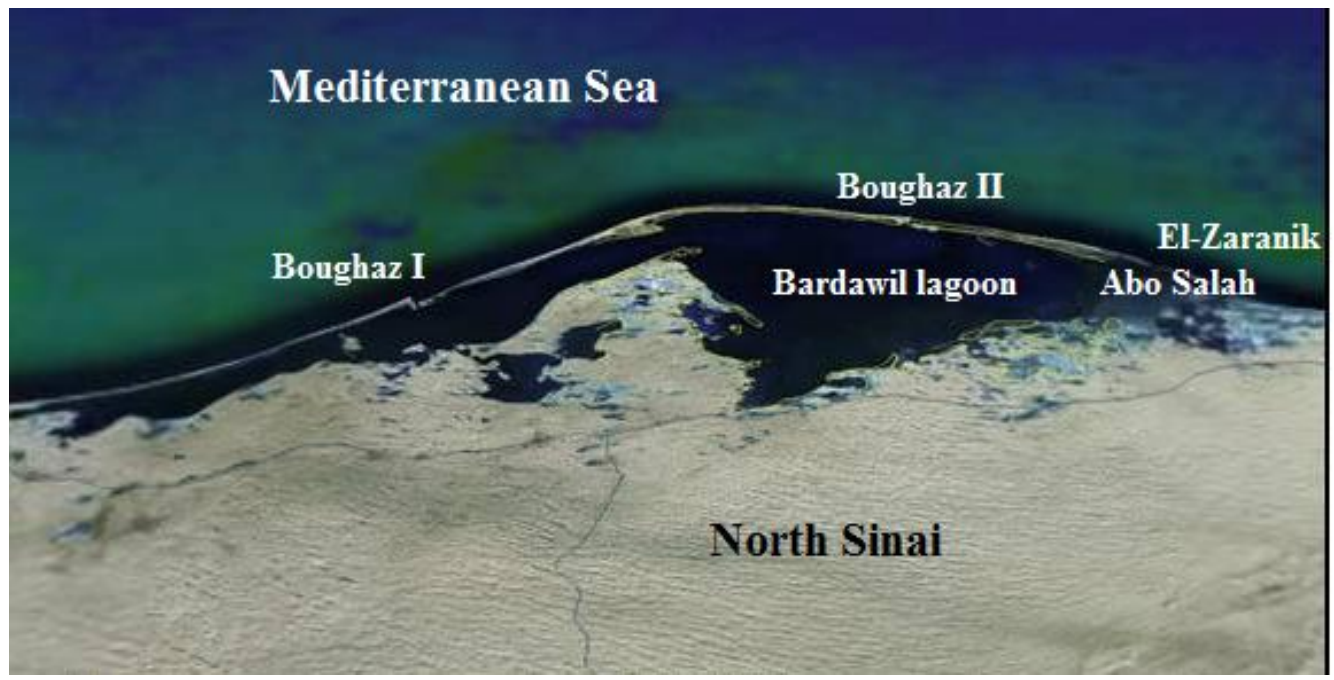

Fig. 1. Bardawil Lagoon

\section{MATERIALS AND METHODS}

\section{Collection of Fishery Statistics}

Data concerning the monthly and annual catch of different fish species and fishing effort of Bardawil lagoon were obtained from the General authority for Fish Resources Development annual statistical book (GAFRD, 2018).

\section{Sampling and catch composition}

Monthly random samples of different fish species were collected from the landing sites along Bardawil lagoon during the fishing seasons 2017/2018 and 2018/2019 from 
May to December to investigate the length frequency distribution of the commercial species. While the catch composition of the different fishing gears was recorded during the monthly field trips to the lagoon fishery (Fig. 2).

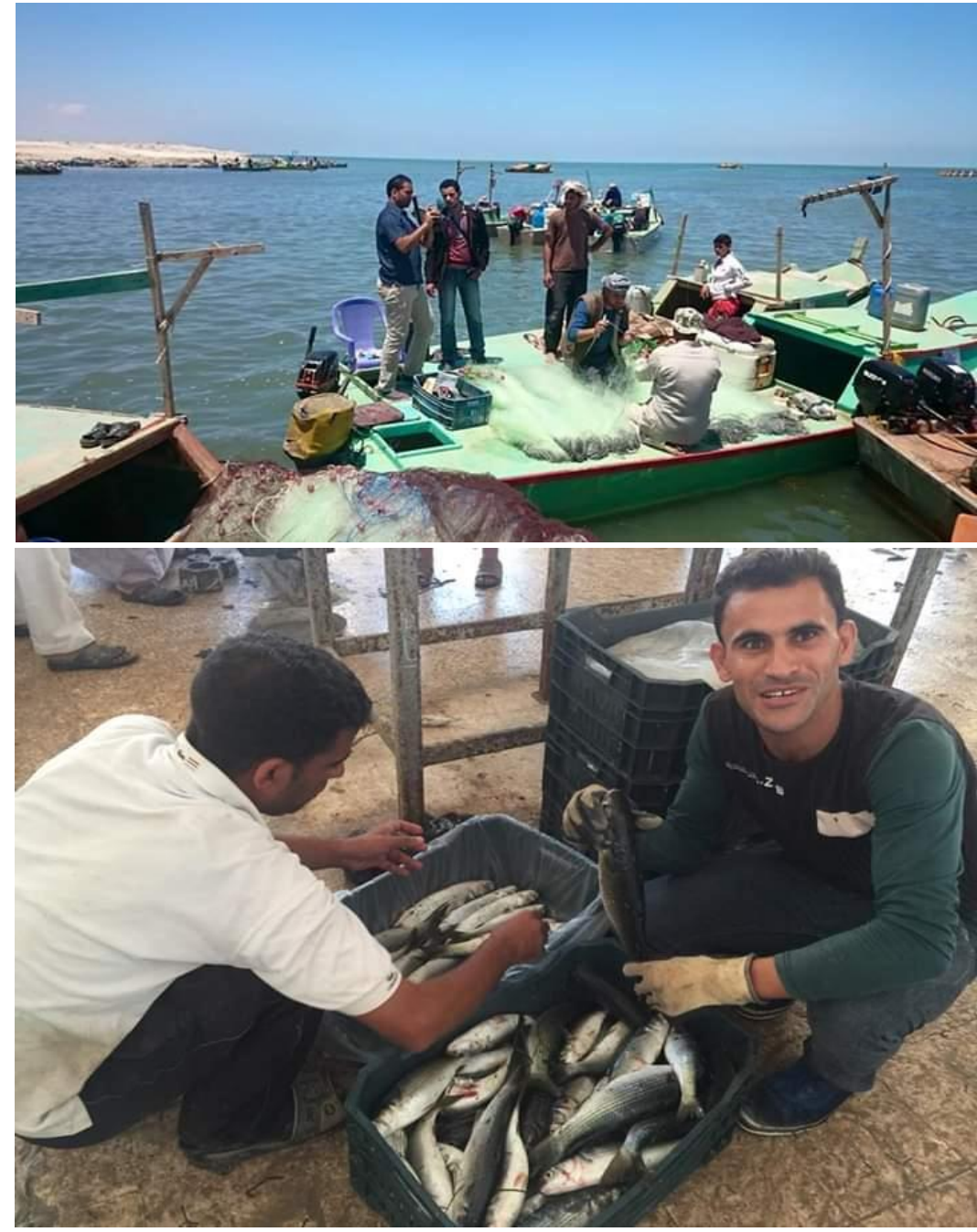

Fig. 2. Sampling procedure in Bardawil Lagoon

\section{Biological measurements}

Length measurements made on total body length for each specimen to nearest millimeter and sorted afterwards in sequential length groups of one centimeter interval.

\section{Length frequency distribution}

Length frequency distribution for the common species in Bardawil lagoon was determined and the percentage of occurrence of each length class was obtained according to Gayanilo et al. (1997\&2003).

\section{Length at first capture $\left(L_{c}\right)$}

The length at first capture (Lc); the length at which $50 \%$ of the fish species retained in the gear for the most common fish species in Bardawil lagoon was estimated from the length frequency distribution as described in Sparre and Venema (1998). 


\section{RESULTS AND DISCUSSION}

\section{Fishing gears and catch composition}

\subsection{The Dabba fishing technique (Trammel nets)}

Dabba (Fig. 3) is the main fishing method in Bardawil lagoon and constituting about $92 \%$ of the fishing fleet in the lagoon. Dabba fishing vessels contributed by 1144 and 1120 fishing vessels. Each fishing vessel reaches about 6-7 m in length and $1.8 \mathrm{~m}$ average width, motorized by outboards of 8 to $10 \mathrm{hp}$; two or three fishermen are working on each vessel.

The fishing gear is trammel nets of Italian type; each unit has $30 \mathrm{~m}$ average length. The two external layers of the net have $120 \mathrm{~mm}$ mesh size and $2 \mathrm{~m}$ depth, while the middle layer has smaller mesh size of about $33 \mathrm{~mm}$ and about $3 \mathrm{~m}$ depth. The fishing gear includes 30 fishing units of trammel net and reached $900 \mathrm{~m}$ in length. Each fishing gear is supported by an upper rope that has floating units, separated from each other by about $80 \mathrm{~cm}$, and has a lower rope loaded by parts of lead with an average weight of $50 \mathrm{~g}$ and separated from each other by about $40 \mathrm{~cm}$.

Fishermen spread the net in water daily with the sun set and collected it at early morning of the next day. Catch of Dabba is composed of gilthead sea bream Sparus aurata, Sea basses Dicentrarchus labrax and D. punctatus, soles Solea solea and S. aegyptiaca, grey mullets, Mugil cephalus, crabs Portunus pelagicus and Callinectes sapidus and shrimps Penaeus japonicus, P. semisulcatus, P. kerathurus and Metapenaeus spp.

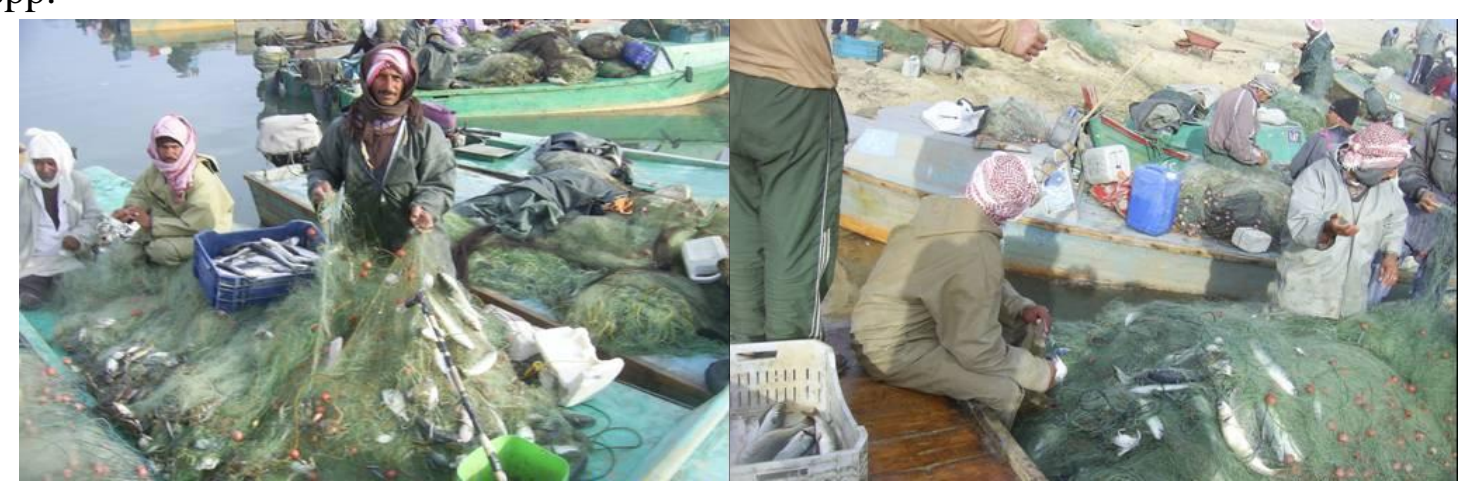

Fig. 3. Dabba fishing gear in Bardawil Lagoon

\subsection{The veranda fishing gear or "Bouss "}

This method (Fig. 4) constituting about $7 \%$ of the fishing fleet in Bardawil lagoon. The number of fishing vessels of veranda type working in Bardawil lagoon during 2010 and 2011 were 84 and 108, respectively. The fishing by this technique depends upon the aggregation of 4 vessels together; two of them motorized by 15-30 hp outboard and the other two are un-motorized and used for carrying nets. 14-20 fishermen operate on each group of vessels (4 vessels). Bouss fishing nets consists of two parts, one horizontal and the other vertical. The vertical part of one layer with 18-26 mm mesh size. Its length is about $600 \mathrm{~m}$ with depth of $5 \mathrm{~m}$. The net is kept vertically in water by floating 
parts or rubber of $40 \mathrm{~cm}$ distances between each other and loaded from the bottom by parts of lead in $50 \mathrm{~cm}$ distance between each two successive parts. The horizontal part is three layers net supported by units of Bamboo make it spread in water. Its length is about $600 \mathrm{~m}$ with width of $4 \mathrm{~m}$, while the mesh size is $120 \mathrm{~mm}$ for the external two layers and $20 \mathrm{~mm}$ for the middle one. This fishing gear is used only for catching grey mullets. Each fishing operation takes about 2 hour and repeated for 4-5 times per day.

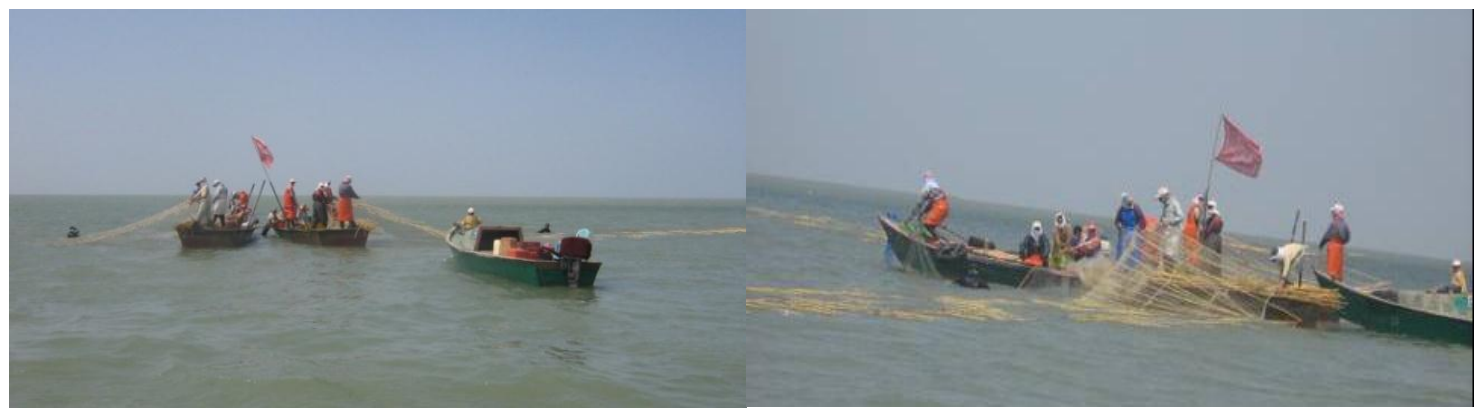

Fig. 4. Veranda fishing gear in Bardawil lagoon

\subsection{Line fishing technique (Sinnar)}

The lines gears operating in the Bardawil lagoon are long and hand lines. In the long-line method, the mainline is of 300 to $450 \mathrm{~m}$ length to which 250 to 300 branch lines are attached. Each branch line has a hook of about 50 to $60 \mathrm{~cm}$ length. The baits used in this method are the small shrimps and grey mullets and the main catch is eels and groupers. In the hand-line, hooks are used individually to catch single fish, while light are used to attract fishes. This method of fishing operated only to catch the nocturnal fishes and its main catch is Dicentrarchus labrax, D. punctatus and eel which appeared in the lagoon recently.

\subsection{Dahbana fishing technique (purse seine)}

The dahbana gear (chancholla) is working at night for catching Liza ramada and L. aurata but it is a destructive gear for the sea bream juveniles. It is a trammel net used by Dabba fishing boats to catch mullets.

\subsection{Isfinkes fishing technique}

The sphinx nets are of three layers with 28-30 mm mesh size. Its height is less than $1 \mathrm{~m}$. The net is kept vertically in water by floating parts or rubber and loaded from the bottom by parts of lead. Isfinkes nets are very cheap and not need boats to use. This type of nets not allowed to use in the lagoon but the fishermen used it for catching the soles fingerlings.

Besides these methods, there are some illegal fishing gears operating in the lagoon in the different months according to the appearance and abundance of the different 
species (Bardawil book, 2008), for example the Madad gear for catching the groupers and meagers and the crab nets.

\section{Catch composition}

Most of fish species inhabiting Bardawil lagoon and in particular all commercial fish species do not reproduce in the lagoon (catadromous species). The most important commercially exploited fish species in the lagoon are gilthead seabream, seabass, grey mullets and soles. Mugil cephalus constitutes the bulk of the catch among the grey mullets. Whereas, Liza ramada, L. aurata, L. saliens, L. carinata and Chelon labrosus are caught in some numbers. Both of Dicentrarchus labrax and D. punctatus are common, but the former is more numerous and attains large sizes. Argyrosomus regius and Epinephalus aeneus are caught in small quantities. Crenidens crenidens, a Red sea immigrant fish, can occasionally be found in the commercial catch. Fish species which reproducing in the lagoon are Atherina boyeri, Aphanius dispar, A. fasciatus, Pomatoschistus marrmoratus and Syngnathus abaster. Ben-Tuvia (1979) listed over 60 species of fishes collected from the lagoon. The species found are by nature eurytopic, especially in their tolerance to both low and high salinity. Surprisingly, Tilapia zillii fishes in the lagoon have been reported during 1971 (Chervinski 1972). The lagoon serves as a nursery ground for juvenile shrimps; Metapenaeus stebbingi, M. monoceros and Penaeus semisulcatus (Tandler, 1972; Ben-Tuvia \& Gilboa, 1975; Tom, 1979). Levinsohn (1980) pointed out to the importance of sea grass which gives the shelter to M. stebbingi, the most abundant shrimp in the lagoon. Whereas, young $P$. semisulcatus and $M$. monoceros were found only near the inlets. These species along with swimming crab (Portunus pelagicus, Charybdis spp. and Callinectes spp.) are abundant on muddy bottoms in the Mediterranean off Bardawil.

By 1990, the catch composition of the lagoon was greatly changed, crustaceans (shrimp and crab) landings have greatly increased annually in Bardawil lagoon, reaching about 50 percent of the total catch, affecting the catch of other economic fish species like seabream and seabass (Mehanna, 2006a, b \& c; Khalil and Shaltut, 2006). Many driving factors which alter the ecological condition of the lagoon as well as biological balance were responsible for this dramatic change. The serious decline of seabass and seabream stocks, the common predators for shrimp and crab and prohibition of Cioncholla fishing gear in 1993 leads to restoration of sea grass beds in the lagoon, which represent a suitable ecological niche for shrimps (Tom et al., 1984),

The appearance of crustacea motivates fishermen to adopt the kalsa fishing technique (trawl nets) to catch crustacea. This fishing method was destructive contributed in catching fish fry, especially bottom feeder like seabream and seabass, and progressive decline and collapse of their stocks (Mehanna, 2006).

The Mugilid species such as Mugil cephalus, Liza ramada, and L. aurata in Bardawil lagoon contributed about $26 \%$ of the total catch during the period from 2005 to 
2018 (Fig. 5) followed by Sparus aurata (Sparidae) which constituted about 6.7\%; Solea solea and S. aegyptiaca (Soleidae) forming about 4.5\%. Seabass such as Dicentrarchus labrax and D. punctatus (Moronidae) constituting about 1.7\%, while Argyrosomus regius (Sciaenidae) along with Epinephelus aenus (Serranidae) are forming up to $0.5 \%$. Crustaceans in the lagoon are represented in the catch by shrimp mainly Metapenaeus stebbingi $(21.5 \%)$ and crabs mainly Portunus pelagicus (31.3\%) (Fig. 5). In addition, the "others" group that contains the unsorted species or those of lesser importance. This group contains Anguilla anguilla (Anguillidae); Terapon puta (Terapontidae); Siganus spp. (Siganidae); Hemiramphus far (Hemiramphidae); Tylosurus spp. (Belonidae) and Tilapia zillii (Cichlidae).

Moreover, water salinity decrease gave the chance to several fish species inhabiting Mediterranean coast off Bardawil lagoon to find a save shelter and rich grazing area in the lagoon. In addition, those species find their ways to unoccupied trophic levels in the lagoon in favour of the declined eurhaline native species.

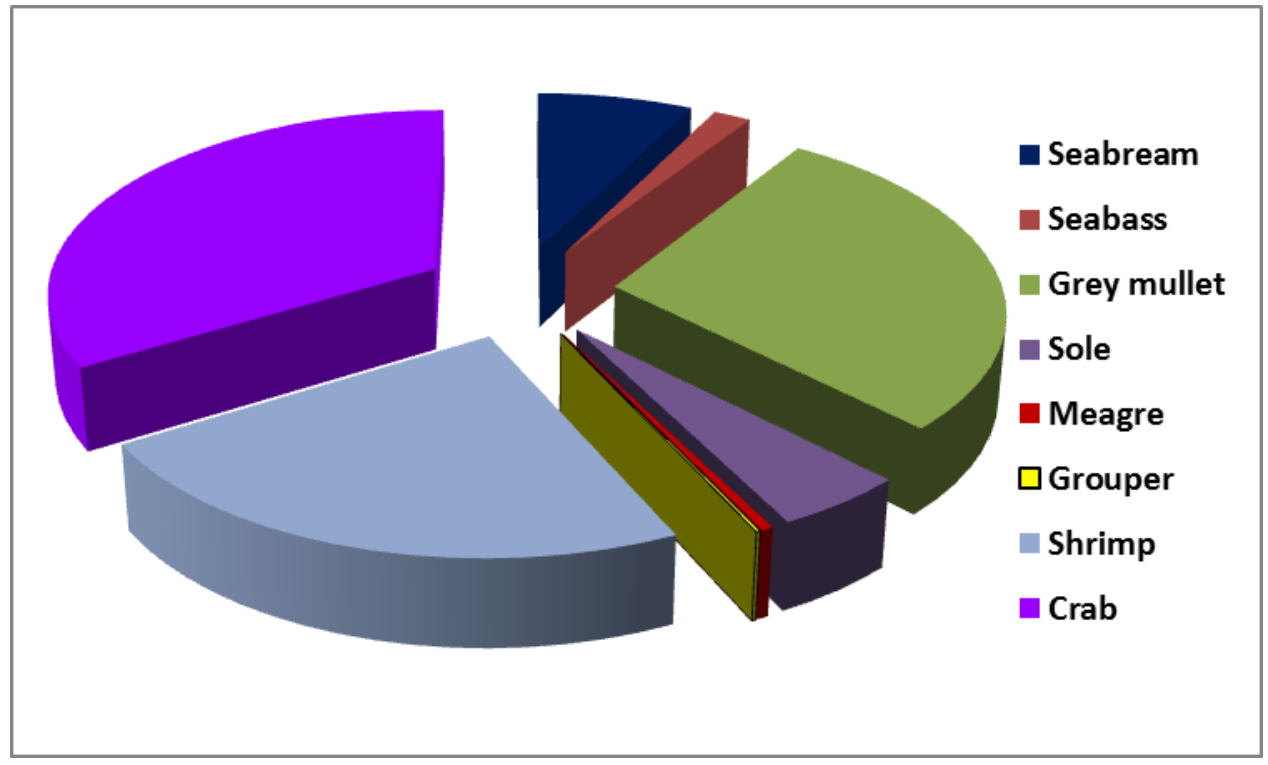

Fig. 5. Catch composition in Bardawil lagoon during 2005-2018

\section{Catch trend}

The annual total fish production from Bardawil lagoon during the period from 2005 to 2018 (Fig. 6) fluctuated between a minimum of 2610 ton during 2018 and a maximum value of 5410 ton during 2009 with an average of 4055 ton. The catch of seabream varied from a minimum of 208 ton during 2017 to a maximum of 336 ton during 2008 with a mean of 278 ton. Grey mullet species were fluctuated between a minimum of 733 ton (2013) and a maximum of 1590 ton (2015) with a mean of 1069 ton. Seabass species contributed to a minimum of 29 ton (2011) and a maximum of 124 ton (2016) with a mean of 68 ton during all investigated seasons. The flatfishes catch (Solea spp.) varied between a minimum of 107 ton (2017) and a maximum of 343 ton (2008) with a mean of 182 ton. The shrimp catch varied between a minimum of 43 ton (2018) 
and a maximum of 1569 ton (2007) with a mean value of 873 ton. The crab catch fluctuated between a minimum of 519 ton during 2014 and a maximum of 2071 ton during 2009 with a mean value of 1268 ton during the period from 2005 to 2018.

Generally, the fish production in Bardawil lagoon shows a decreasing trend during the period of study and the same trend is noticed for all the commercial species except for European seabass and grey mullet. For shrimp, a sharp decreasing was observed since 2015 this coincide with banning the kalsa fishing gear (bottom trawl net).

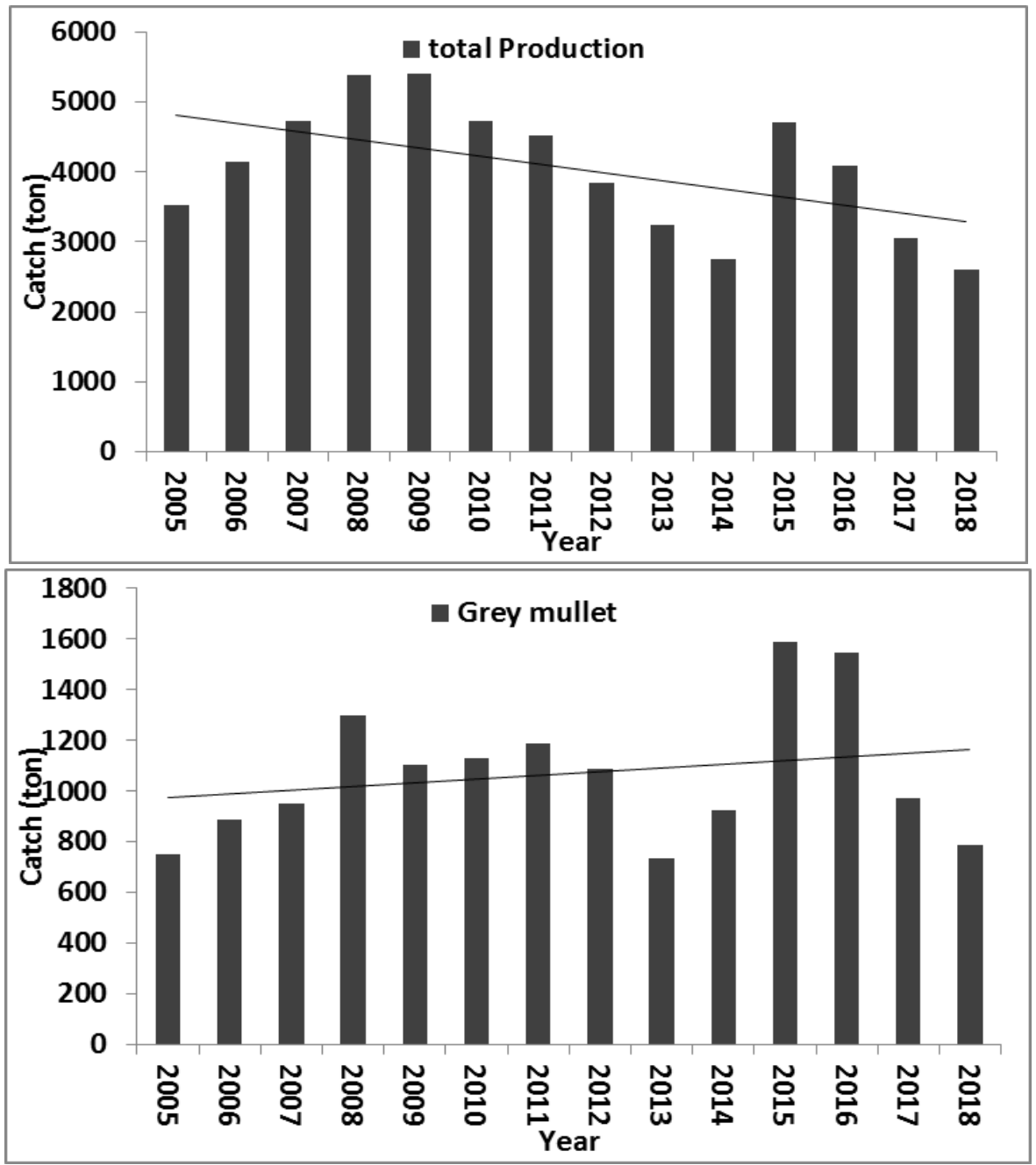



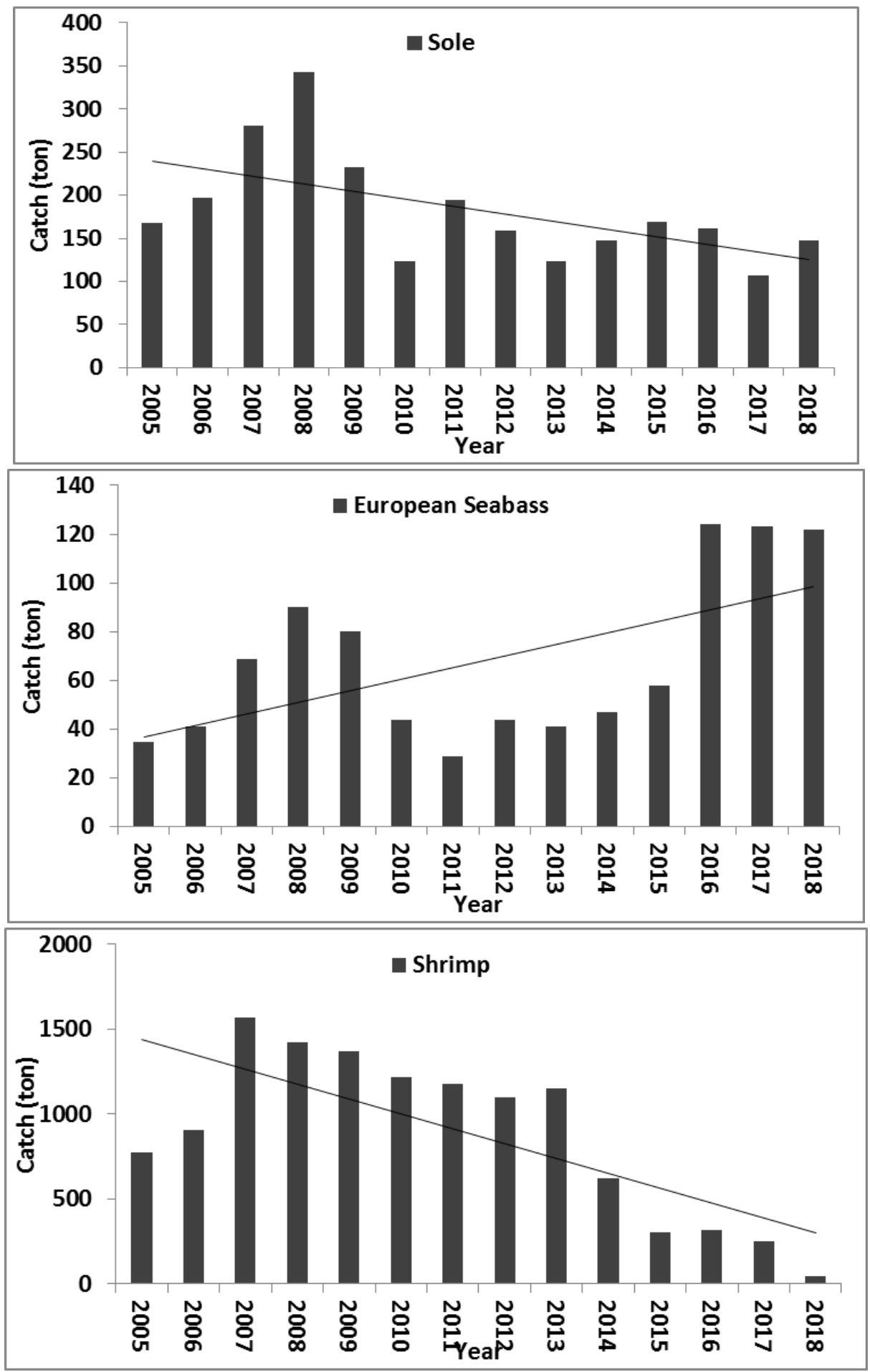


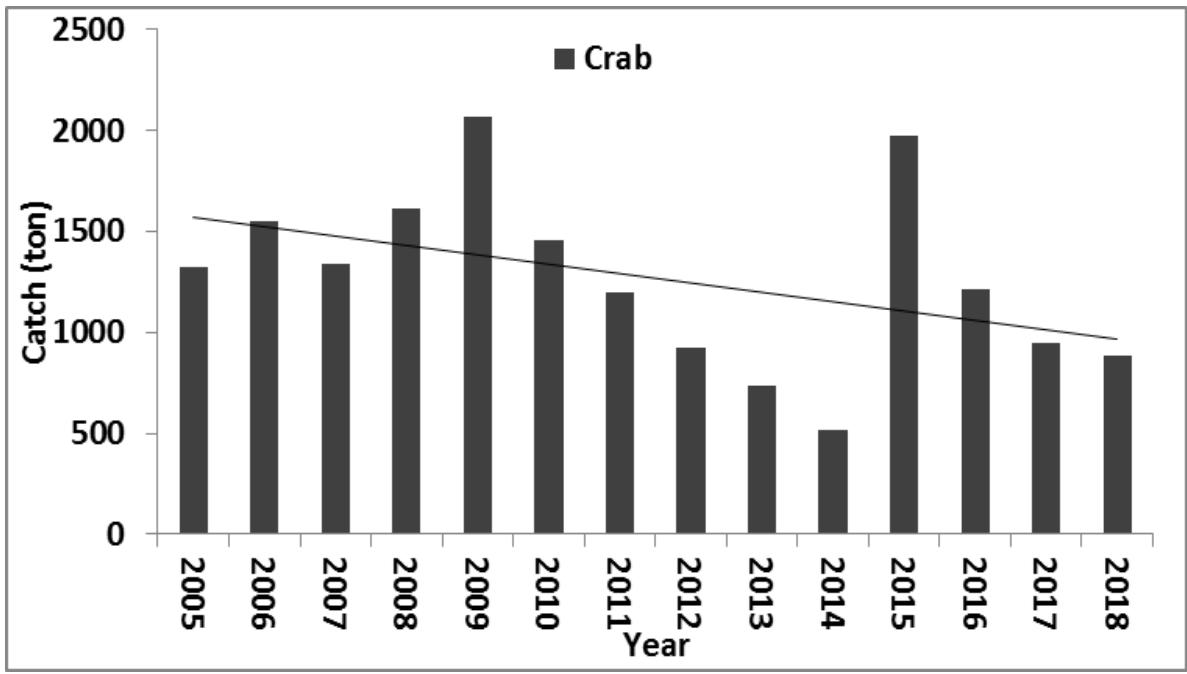

Fig. 6. Catch trend for total and commercial species in Bardawil Lagoon

\section{Length frequency distribution for the common species}

Length frequency data have a practical application in the field of fisheries science. The analysis of length-frequency data can be used for the estimation of age, growth, survival and mortality rates (Pauly, 1980, 1983, 1984 \& 1987). Also, in fishes, size is generally more biologically relevant than age, mainly because several ecological and physiological factors are more size-dependent than age-dependent. Consequently, variability in size has important implications for diverse aspects of fisheries science and population dynamics (Erzini et al., 1999). The length frequency distribution also is applied in some analytical yield models such as the yield per recruit models of Beverton \& Holt (1957).

\subsection{Grey mullet}

The grey mullets are the most abundant fish species inhabiting Bardawil lagoon. They form about $26 \%$ of the total lagoon production. In 2018, 789 ton of grey mullets were landed forming a net profit of about 40 million Egyptian pounds. Mullet's catch is composed mainly from Mugil cephalus, Liza ramada and L. aurata, while both Chelon labrosus and L. saliens are found in very small amounts and recorded under the "others" group.

The length frequency for 320 L. ramada, 280 M. cephalus, 150 L. aurata and 200 specimens of Chelon labrosus was grouped in $1 \mathrm{~cm}$ length groups to construct the length frequency distribution (Fig. 7). The total length was ranged from 12 to $44 \mathrm{~cm}$ TL for $L$. ramada, from $14.0 \mathrm{~cm}$ to $59 \mathrm{~cm}$ for $M$. cephalus, from 13 to $30 \mathrm{~cm}$ for L. aurata and from $15.0 \mathrm{~cm}$ to $35 \mathrm{~cm}$ for Chelon labrosus. The most frequent lengths in the sample were from 19 to $28 \mathrm{~cm}$ for L. ramada, from $24 \mathrm{~cm}$ to $40 \mathrm{~cm}$ for M. cephalus, from 16 to $20 \mathrm{~cm}$ for L. aurata and from 19 to $25 \mathrm{~cm}$ for C. labrosus. 

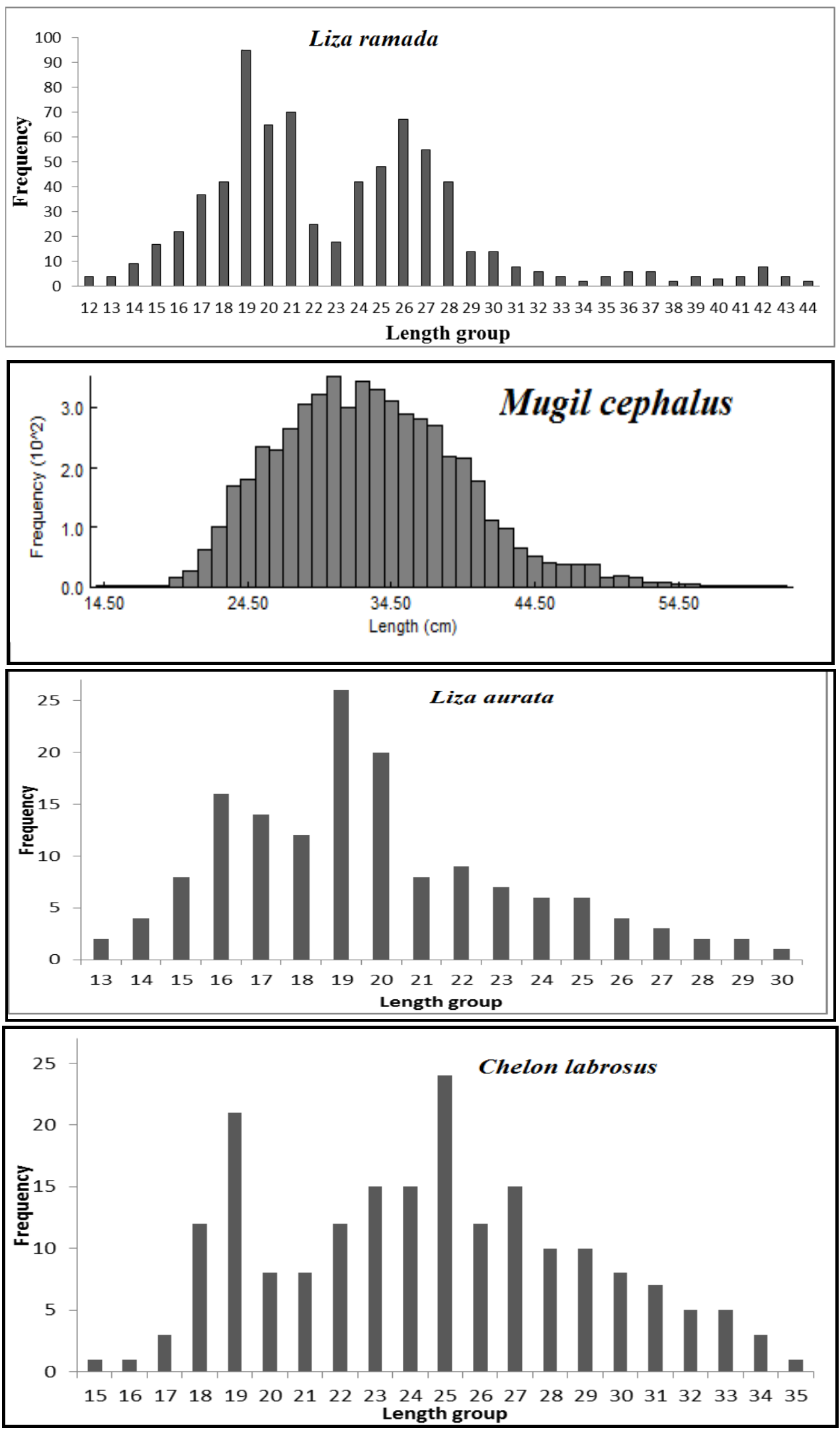

Fig. 7. Length frequency distribution of Grey mullet in Bardawil Lagoon 


\subsection{Seabream Sparus aurata}

A total of 345 seabream were measured. The lengths of the fish caught varied from $13.0 \mathrm{~cm}$ to $33.0 \mathrm{~cm}$ and the great majority of the annual catch was composed of the individuals from $17 \mathrm{~cm}$ to $21 \mathrm{~cm}$ (Fig. 8).

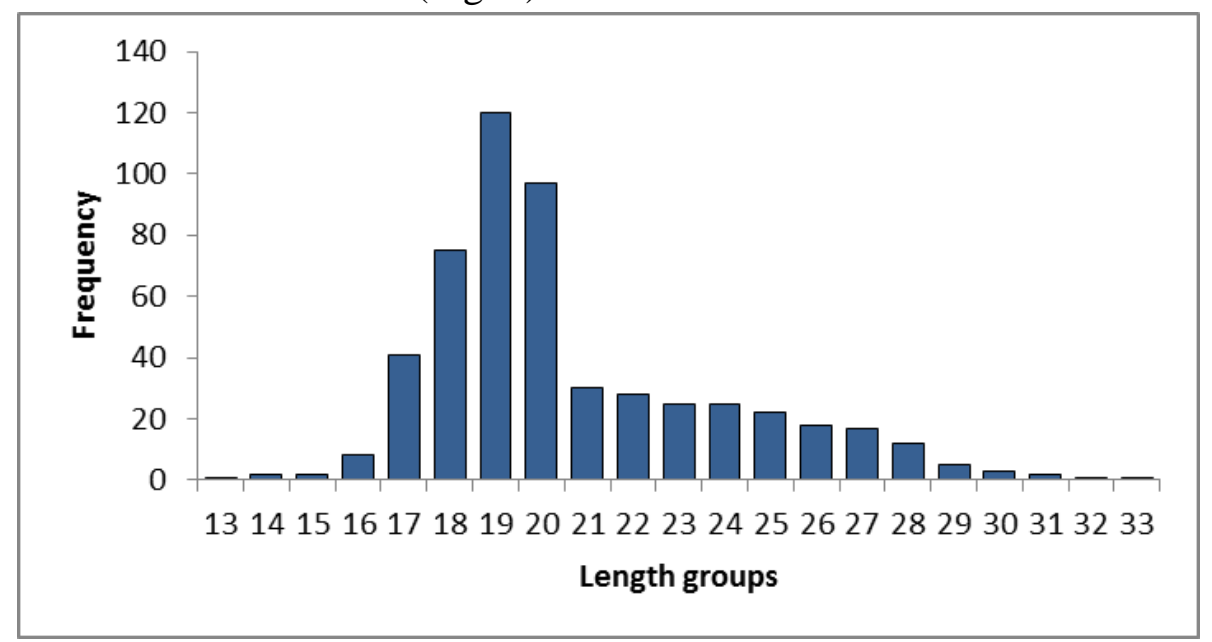

Fig. 8. Length frequency distribution of Sparus aurata in Bardawil lagoon

\subsection{European seabass}

A total of 159 individuals of Dicentrarchus labrax were examined and the length of the examined samples were ranged in length from 20.0 to $55.7 \mathrm{~cm}$ total length. Lengthfrequency distributions of individuals were shown in (Fig. 9).

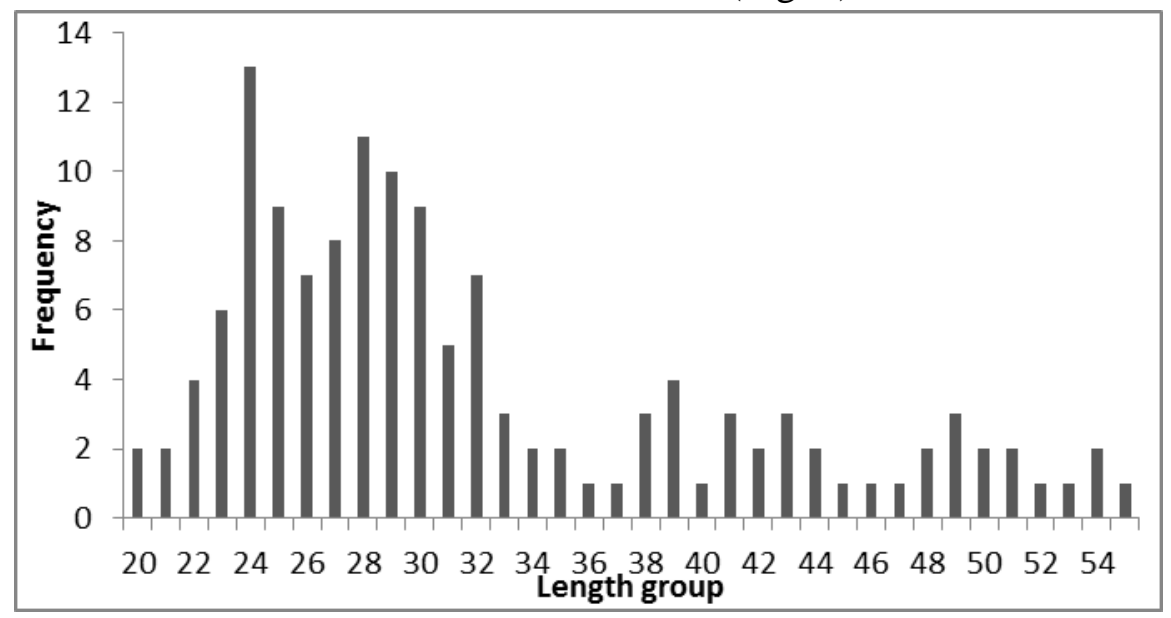

Fig. 9. Length frequency distribution of Dicentrarchus labrax in Bardawil lagoon

Mehanna (2006) mentioned that seabasses are exploited by two fishing methods in the Bardawil lagoon; trammel nets and lines. The length frequency of seabass caught by trammel nets was smaller than that by lines, where the length of seabasses fished by trammel nets ranged between 16 and $30 \mathrm{~cm}$ TL for D. labrax and that fished by hook and lines ranged between 26 and $71 \mathrm{~cm}$ TL for D. labrax. She concluded that the fishes of lengths greater than $60 \mathrm{~cm}$ for D. labrax were rarely reported in the catch. 


\subsection{Soles}

The soles catch in Bardawil lagoon composed of two species, the common sole, Solea solea and the Egyptian sole $S$. aegyptiaca. They are exploiting by trammel nets (locally known as Dabba) and earning up to 10 million LE annually. A total of 2000 individuals were measured (1200 S. aegyptiaca and $800 \mathrm{~S}$. solea). The total length was varied between 9.0 and $34.8 \mathrm{~cm}$ for $S$. solea and between 11.0 and $30.5 \mathrm{~cm}$ for $S$. aegyptiaca (Fig.10).

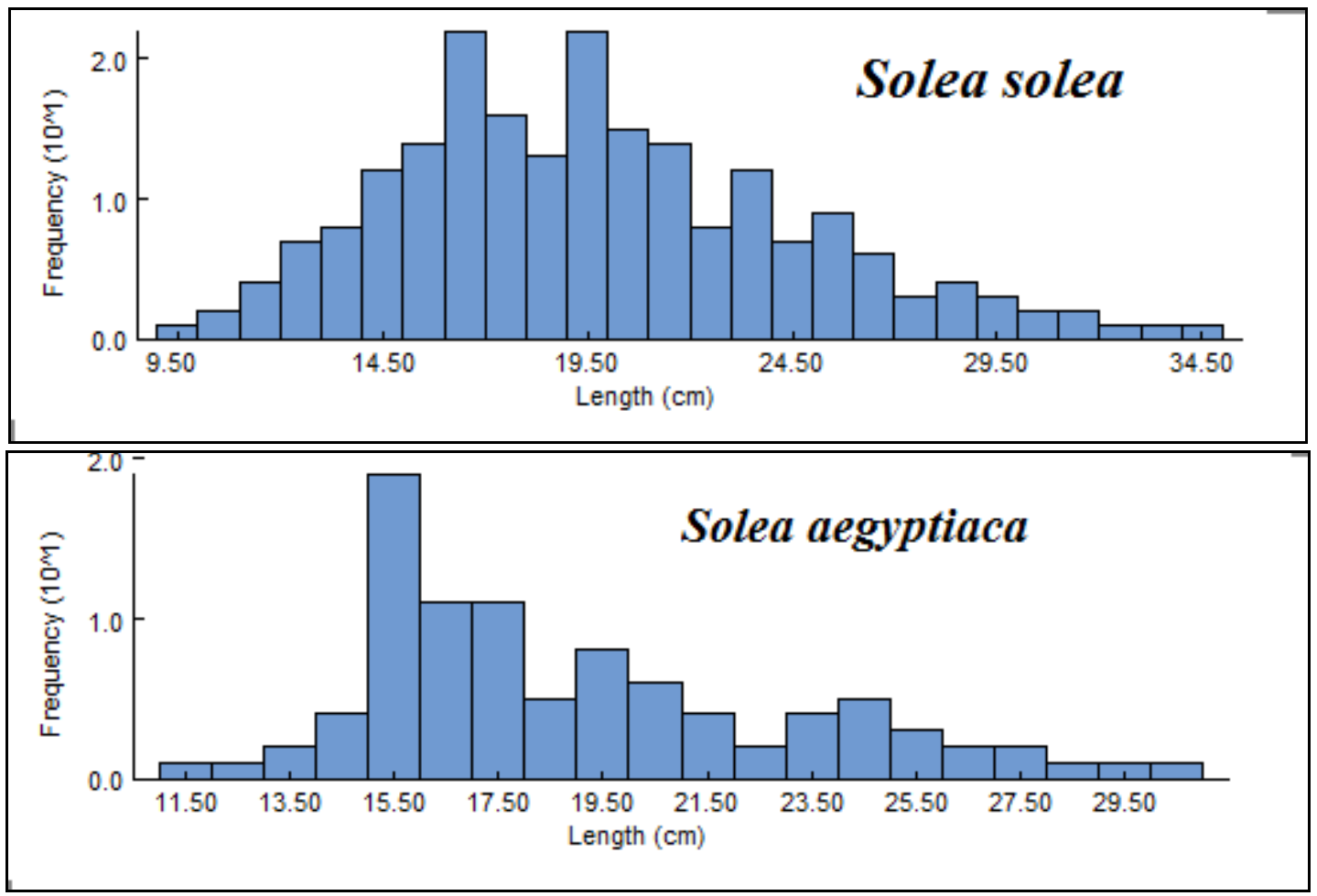

Fig. 10. Length frequency distribution of Sole species in Bardawil lagoon

\section{Length at first capture for the important species}

Length at first capture (Lc) has a great importance in the fisheries management as it is an indication for the suitability of mesh size. The length at first capture at which 50\% of the fish are vulnerable to capture for the most important species in Bardawil lagoon was given as $19.1 \mathrm{~cm}$ for Sparus aurata, $27.9 \mathrm{~cm}$ for Mugil cephalus, $18.8 \mathrm{~cm}$ for Liza ramada, $15.9 \mathrm{~cm}$ for Solea solea, $24.5 \mathrm{~cm}$ for Dicentrarchus labrax. It is obvious that, the length at first capture is smaller than the length at first sexual maturity reported for these species in the previous studies indicating the overexploitation situation due to the small mesh sizes used in Bardawil lagoon (Khalifa, 2005; Mehanna and Khalil, 2006; Mehanna, 2007a\&b; Mehanna et al., 2010; Mehanna et al., 2011; Mehanna et al., 2013; Mehanna et al., 2014; Salem and El-Aiatt, 2012; Mehanna and Hegazi, 2013; Salman, 2014; Mahmoud, 2019). 


\section{CONCLUSION}

In conclusion, fisheries management includes different management measures. Among these are technical regulations on fishing gears in order to obtain the overall goal of high sustainable yield in the fisheries. These regulations for example, the urgent increase of mesh size to improve the selective properties of a fishing gear so that bycatches of juvenile fish are reduced. This action will safeguard recruitment to the larger size groups of a fish stock including the spawning stock. Also, the mitigation of the negative impact of fishing gears on the ecosystem and the biodiversity through the prohibition of the destructive ones is another example. From this work, the fishing gears used in Bardawil lagoon need to improve their selectivity and increase their mesh sizes.

\section{REFERENCES}

Ben-Tuvia, A. (1979). Studies on the population and fisheries of Sparus aurata in the Bardawil lagoon eastern Mediterranean. Invest. Pesq. Earc.,43 (1): 43-67.

Ben-Tuvia, A and Gilboa (1975). Progress report on the fishery research in Bardawil lagoon for the year 1974-1975. Haifa, Israel Oceanography and limnological research 1 Lt. 59pp.

Beverton, R. J . and Holt, S. J. (1957). On the dynamics of exploited fish populations . Fish .Invest. London. Ser. 2, 19. 533pp.

Chervinski, J. (1972). Occurrence of Tilapia zillii (Gervais) (Pisces, Cichlidae) in the Bardawil lagoon in northern Sinai. Bamidgeh, 24: 49-50.

Erzini, K.; Gonçalves, J.M.S.; Bentes, L.; Lino, P.G. and Ribeiro, J. (1999). Catch composition, catch rates and size selectivity of three long-line methods in the Algarve (southern Portugal). Bol. Inst. Esp. Oceanogr. 15 (1-4): 313-323.

Farouk, A. (2014). Studies on water Quality, pollution by heavy metals in water, Soil \& Fish and stock assessment in Bardawil lagoon. PhD. Thesis, Faculty of Science, Al-Azhar University.

GAFRD (2018). Annual statistical report of General Authority for Fish Resources Development GAFRD, 2018.

Gayanilo, F.C.; Sparre, P. and Pauly, D. (1997). FAO-ICLARM Stock Assessment Tools. Reference manual. ICLARM (International Center for Living Aquatic Resources Management Food and Agricultural Organisation of the United Nation). Rome., 262pp.

Gayanilo, F.C.; Sparre, P.; and Pauly, D. (2003). FAO-ICLARM stock assessment tool (FiSAT II) User's Guide, FAO Computerized Information Series (Fisheries). No. 8, Rome, FAO, 266pp.

Khalifa, U. S. (1995). Biological studies on gilthead bream, Sparus aurata Linn. (pisces: Sparidae) in lake Baradwil. M. Sc. Thesis. Fac. Sci. Cairo Univ. 361pp.

Khalifa, U. S. (2005). Population characteristics and fisheries management of European seabass Dicentrarchus labrax L., in Bardawil lagoon, Egypt. Afr. J. Biol. Sci., 1 (1): 69-78. 
Khalil, M. T. and Shaltout, K. H. (2006). Lake Bardawil: Zaranik Protected Area. Publication of National Biodiversity Unit No. 15, Egyptian Environmental Affairs Agency (EEAA), Cairo, 599pp.

Mahmoud, H. S. (2019). Biological and dynamical studies on the black-barred halfbeak (family: hemiramphidae) in bardawil lagoon. MSc Thesis, Arish University.

Mehanna, S. F. (2006a). Lake Bardawil fisheries: current status and future sight. J. Egyp. Ger. Soc. Zool., 51(D): 91-105.

Mehanna, S. F. (2006b). Fisheries management of the thinlip grey mullet Liza ramada and golden grey mullet Liza aurata from Lake Bardawil, Egypt. Egyp. J. Aquat. Biol.\& Fish., 10 (2): 33-53.

Mehanna, S. F. (2006c). Fisheries regulations based on yield per recruit analysis for the spotted seabass Dicentrarchus punctatus (Moronidae) at Bardawil lagoon, Mediterranean coast of Sinai, Egypt. Egyp. J. Aquat. Biol. \& Fish., 10 (4): 129-145.

Mehanna, S. F. (2007a). Stock assessment and management of the Egyptian sole Solea aegyptiaca Chabanaud, 1927 (Osteichthyes: Soleidae), in the Southeastern Mediterranean, Egypt in the Eastern Mediterranean (Port Said region), Egypt. Turk. J. Zool., 31: 379-388.

Mehanna, S. F. (2007b). A preliminary assessment and management of gilthead bream Sparus aurata in Port Said fishery, Southeastern Mediterranean, Egypt. Tur. J. Fish. \& Aquat. Sci., 7 (2): 123-130.

Mehanna, S. F. (2013). Sustainable development of Bardawil lagoon fisheries. First Regional Symposium on Sustainable Small-Scale Fisheries 27 - 30 November 2013, St. Julian's Malta.

Mehanna, S. F. (2014). Reproductive dynamics of the common sole Solea solea (Linnaeus, 1758) from Bardawil lagoon, North Sinai, Egypt. Tropentag 2014: Bridging the gap between increasing knowledge and decreasing resources, September 17-19, 2014, Czech University of Life Sciences Prague, Czech Republic.

Mehanna, S. F. (2020). Challenges faced the small scale fisheries and its sustainable development. ICAR- Central Marine Fisheries Research Institute, Research Centre Mangalore, 7-10 January 2020.

Mehanna, S. F.; Ameran, M.; El-Aiatt, A. and Salem, M. (2010). Population dynamics of the Egyptian sole Solea aegyptiaca (Soleidae) at Bardawil lagoon, Mediterranean coast of Sinai, Egypt. Proceedings of the 3rd Global Fisheries and Aquaculture Research Conference, Foreign Agricultural Relations (FAR), Egypt: 210-219.

Mehanna, S. F.; El-Aiatt, A. A.; Ameran, M. and Salem, M. (2010). Population dynamics and fisheries regulations for the European seabass Dicentrarchus labrax (moronidae) at Bardawil lagoon, Egypt. 3rd International conference on Fisheries and Aquaculture, 29 November-1 December, Cairo, Egypt. www.cabdirect.com.

Mehanna, S. F.; El-Aiatt, A. A. and Salem, M. (2011). An investigation of the impacts of shrimp bottom trawling on the Bardawil lagoon fisheries, Egypt. Egyp. J. Aquat. Biol. \& Fish., 15 (3): 369-378.

Mehanna, S. F. and Khalil, M. T. (2006). Lake Bardawil fisheries: in Lake Bardawil: Zaranik Protected Area, Khalil, M.T. and Shaltut, K. (eds). Publication of National Biodiversity Unit No. 15, Egyptian Environmental Affairs Agency (EEAA), Cairo, 599 pp. 
Mehanna, S. F. and Hegazi, M. M. (2013). Population dynamics of grey mullet Mugil cephalus associated with seagrass community in Bardawil lagoon, Northern Sinai, Egypt. INOCXIII International Symposium 2013, Malaysia.

Mehanna, S. F.; Hegazi, M. M. and Salman, S. (2013). Age and growth based on the otolith readings of the common sole, Solea solea from Bardawil lagoon. 5th International conference on Fisheries and Aquaculture researches, Cairo, May, 2013.

Mehanna, S. F.; Shaker, I. M. and Farouk, A. (2014). Population dynamics of gilthead seabream Sparus aurata in the Bardawil lagoon, North Sinai, Egypt. 4th scientific conference "Fisheries resources between science and application", Abbasa, 11-13 March 2014.

Mehanna, S. F.; Desouky, M. G. and Makkey, A. F. (2019). Some targeted reference points for thin lip grey mullet Liza ramada management in Bardawil Lagoon, North Sinai, Egypt. Fish. Aqua. J. 10:1 (doi: 10.4172/2150-3508.1000263)

Mehanna, S. F.; Desouky, M. G. and Farouk, A. E. (2019). Population dynamics and fisheries characteristics of the Blue Crab Callinectes sapidus (Rathbun, 1896) as an invasive species in Bardawil Lagoon, Egypt. Egyptian Journal of Aquatic Biology \& Fisheries, 23(2): 599-611.

Mehanna, S. F.; Desouky, G.; Salem, M. and Mahmoud, H. S. (2019). Some biological aspects and reproductive dynamic of the black-barred halfbeak Hemiramphus far (family: Hemiramphidae) in Bardawil lagoon, Egypt. Egyptian Journal of Aquatic Biology \& Fisheries, 23(3): 127-137.

Pauly, D. (1980). On the interrelationships between natural mortality, growth parameters and mean environmental temperature in 175 fish stocks. J. Cons. CIEM, 39 (3): 175-192.

Pauly, D. (1983). Length-converted catch curves. A powerful tool for fisheries research in the tropics. Part 1. ICLARM Fishbyte,1(2): 9-13.

Pauly, D. (1984). Length-converted catch curves. A powerful tool for fisheries research in the tropics. (part II) . ICLARM Fishbyte, 2 (1): 17-19.

Pauly, D. (1987). A review of the ELEFAN system for analysis of length- frequency data in fish and aquatic invertebrates. ICLARM Conf. Proc., 13: 7-34.

Salem, M. and El-Aiatt, A. (2012). Population dynamics and fisheries management of Penaeus semisulcatus exploited by shrimp trawl of Bardawil Lagoon, North Sinai, Egypt. Egyptian Journal of Animal production, 49: 185-191.

Salman, S. (2014). Fisheries characteristics and population dynamics of commercial species of family Soleidae at Bardawil Lagoon, North Sinai, Egypt. MSc. Thesis, Suez Canal University.

Sparre, P. and Venema, S.C. (1998). Introduction to Tropical Fish Stock Assessment. FAO Fisheries Technical Paper, 306/1, Rev. 2, Rome, 579pp.

Tandler, A. (1972). Shrimp survey. In Research in the Bardawil lagoon. Haifa. Israel Oceanogr. and limnology. Research Ltd. pp. 41-2.

Tom, M. (1979). Survey of the commercial shrimp population off the Mediterranean coast of Sinai: Part 3. Fish fishbread Isr. 14 (3): 31-5.

Tom, M.; Shlagman, A. and Lewinsohn, Ch. (1984). The Benthic phase of the life cycle of Penaeus semisulcatus, De Haan (Crustacea, Decapoda) along the southeastern coast of the Mediterranean P. S. Z. N. I. Marine Ecology, 5 (3): 229-241. 